УДК 373.3.011.3-051:005.336.5]:364-152(043.5)

DOI https://doi.org/10.32782/apv/2021.6.8

\title{
Неля КІНАХ
}

кандидат економічних наук, доиент кафедри педагогіки та психологї̈, Волинський інститут післядипломної педагогічної освіти, вул. Винниченка, 31, м. Луиьк, Волинська область, Україна, 43006

ORCID: 0000-0002-9025-6514

Бібліографічний опис статті: Кінах, Н. (2021). Критерії та показники сформованості професійно-педагогічного підприємництва вчителя початкової школи. Acta Paedagogica Volynienses, 6, 46-52, doi: https://doi.org/10.32782/apv/2021.6.8

\section{КРИТЕРІЇ ТА ПОКАЗНИКИ СФОРМОВАНОСТІ ПРОФЕСІЙНО-ПЕДАГОГІЧНОГО ПІДПРИЄМНИЦТВА ВЧИТЕЛЯ ПОЧАТКОВОЇ ШКОЛИ}

\begin{abstract}
У статті розглянуто аспекти формування професійно-педагогічного підприємництва учителя початкової школи на основі визначення критеріїв і показників, щуо його визначають. Здійснено дефінітивний аналіз наукових розвідок з питань визначення критерї̈в і показників у педагогічному дослідженні, а також визначено ознаки, яким вони повинні задовольняти. Визначення критерї̈ і показників сформованості професійно-педагогічного підприємництва вчителя початкової школи є одним з головних завдань дослідження, оскільки за його відсутності стає неможливим діагностування рівня його сформованості. При визначенні критеріїв та показників сформованості професійно-педагогічного підприємництва вчителів початкової школи необхідно врахувати інтегративний характер взаємозв'язку інваріантів їх професійної компетентності, щзо передбачає комплексний підхід до ї̈ оцінювання. На основі аналізу науково-педагогічної літератури, застосування особистісно-діяльнісного підходу з дотриманням умов об'єктивності, адекватності, валідності, комплексності та інтегративності, а також враховуючи інформатизацію освітнього середовища, нами було визначено такі критерії: мотиваційний, діяльнісний, когнітивний, особистісно-рефлексивний, оцінний, ціннісно-орієнтаційний, професійно-пізнавальний, функціонально-компетентнісний, інформачійно-інтегративний. Визначені нами критерії очінювання в дослідженні конкретизуються показниками, шчо дають можливість точніше охарактеризувати рівні сформованості професійно-педагогічного підприємництва вчителя початкової школи. Перспективою подальших наукових розвідок є добір та розробка відповідного діагностичного інструментарію. Також у системі розроблених критеріїв та показників дочільно встановити мінімальне (порогове) значення, за якого можна констатувати їх сформованість і максимальне значення, а також говорити про високу імовірність використання сформованого професій-
\end{abstract} но-педагогічного підприємництва вчителя в процесі його професійного розвитку та самореалізації.

Ключові слова: професійно-педагогічне підприємнищтво, критерії, показники, вчитель початкової школи, професійна компетентність.

\section{Nelia KINAKH}

Candidate of Economic Sciences, Associate Professor at the Department of Pedagogy and Psychology, Volyn Institute of Postgraduate Pedagogical Education, Vynnychenko str., 31, Lutsk, Volyn region, Ukraine, 43006 ORCID: 0000-0002-9025-6514

To cite this article: Kinakh, N. (2021). Kryterii ta pokaznyky sformovanosti profesiino-pedahohichnoho pidpryiemnytstva vchytelia pochatkovoi shkoly [Criteria and indicators of the formation of professional and pedagogical entrepreneurship of primary school teachers]. Acta Paedagogica Volynienses, 6, 46-52, doi: https://doi.org/10.32782/apv/2021.6.8

\section{CRITERIA AND INDICATORS OF FORMATION OF PROFESSIONAL AND PEDAGOGICAL ENTREPRENEURSHIP OF PRIMARY SCHOOL TEACHER}

The article considers aspects of the formation of professional and pedagogical entrepreneurship of primary school teachers on the basis of determining the criteria and indicators that determine it. A definitive analysis of scientific research on the definition of criteria and indicators in pedagogical research, as well as identified the characteristics that they must meet. Determining the criteria and indicators of the formation of professional and pedagogical entrepreneurship of primary school teachers is one of the main tasks of the study, because in its absence it becomes impossible to diagnose the level of its formation. In determining the criteria and indicators of the formation of professional and pedagogical entrepreneurship of primary school teachers, 
it is necessary to take into account the integrative nature of the relationship of invariants of their professional competence, which provides a comprehensive approach to its evaluation. Based on the analysis of scientific and pedagogical literature, application of personality-activity approach with observance of conditions of objectivity, adequacy, validity, complexity and integrativity, and also taking into account informatization of educational environment, we have defined the following criteria: motivational, activity, cognitive, personality-reflective, evaluative, value-oriented, professional-cognitive, functionalcompetence, information-integrative. The evaluation criteria defined by us in the study are specified by indicators that allow to more accurately characterize the levels of formation of professional and pedagogical entrepreneurship of primary school teachers. The prospect of further scientific research is the selection and development of appropriate diagnostic tools. Also in the system of developed criteria and indicators it is advisable to set a minimum (threshold) value at which their formation and maximum value can be stated, as well as to talk about the high probability of using established professional pedagogical entrepreneurship in the process of professional development and self-realization.

Key words: professional and pedagogical entrepreneurship, criteria, indicators, primary school teacher, professional competence.

Постановка наукової проблеми та їі значення. Нині фінансово-економічна ситуація в Україніє доволі суперечливоюі неоднозначною, тому перехід до ринкової економіки та активна євроінтеграція передбачають значні зміни у системі освіти. Підприємництво $є$ одним з факторів розвитку суспільства, а розвиток підприємництва - запорука економічного і соціокультурного збагачення нації. Відповідно, економічно розвинені суспільства мають більше можливостей для впровадження новітніх технологій. Продиктований потребами сьогоднішнього дня високий рівень вимог до освіти учнів початкових класів може бути реалізований тільки тоді, коли вчитель початкової школи буде високопрофесійним, компетентним фахівцем у своій галузі. Такий фахівець повинен не лише сам мати фундаментальну освітню підготовку і володіти професійними знаннями і вміннями, що відповідають рівню сучасної професійно-педагогічної науки. Він повинен усвідомлювати цілі і значення своєї професійної праці в цілісній системі неперервної освіти, бути професійно мобільним, тобто гнучко реагувати на зміни соціальної ситуації розвитку школи, опановувати нові психологопедагогічні вимоги до педагогічного процесу і нові педагогічні технології. Вчитель повинен володіти усіма ключовими компетентностями для того, щоб сформувати їх у школярів. Адже не можна передати учню того, чого ти сам не маєш і не вмієш робити. Підприємницька освіта дасть змогу вчителю оволодіти необхідним обсягом практичних навичок введення бізнесу, планування комплексу практичних дій, формування моделей індивідуального бізнес-проекту, нагромадження законів підприємницької діяльності. Підготовка вчителя повинна включати як формування системи знань та вмінь для підвищення рівня професійної діяльності, так і розвиток якостей особистості: дбайливого ставлення до власності, вироблення вміння раціонально використовувати наявні ресурси для задоволення освітніх потреб. Тобто формування таких якостей, які б відповідали суспільним інтересам і сприяли всебічному розвиткові особистості. На нашу думку, професійно-педагогічне підприємництво вчителя початкової школи можна розглядати як модель поведінки, яка дозволяє успішно втілювати власні підприємницькі ідеї в життя, вміти планувати свою діяльність, застосовувати творчі та інноваційні підходи до роботи, а в разі потреби - ризикувати.

Аналіз останніх досліджень i публікацій. Актуальні підходи підготовки до підприємницької діяльності висвітлені в змістовних працях С. Мельникова, Р. Пустовій, О. Романовський, О. Тополя та інших науковців. Досвід розробок підприємницьких проектів висвітлений у працях В. Бикова, О. Борисова, С. Вершиніна, О. Парамонова, О. Потапова тощо. Зміст підприємництва, його структуру, умови функціонування, фактори сприяння і стримування розвитку підприємництва досліджували Ю. Авксентьєв, О. Батура, С. Біла, Ю. Благодир, О. Васильєва, Л. Велева, Л. Дідківська, В. Дубровський, Я. Домбровський, I. Запоточний, І. Іванова, Т. Кондратюк, О. Мазур, Ю. Наврузов, Д. Стеченко, О. Титарено, О. Травянко, С. Чистов та ін. Фрагментарно питання формування фахової компетентності з основ підприємництва учителів досліджували В. Вачевський, Л. Козачок, Н. Примаченко.

Мета статті - визначити критерії та показники сформованості професійно-педагогічного підприємництва вчителя початкової школи в умовах трансформаційних змін в освіті.

Виклад основного матеріалу. Визначення критеріїв і показників сформованості професійно-педагогічного підприємництва вчителя початкової школи $є$ одним 3 головних 
завдань дослідження, оскільки за його відсутності стає неможливим діагностування рівня його сформованості. У психолого-педагогічній довідковій літературі термін «критерій» визначається як мірило для визначення, оцінка предмета, явища; ознака, взята за основу класифікації (Гіжевський, 2002). Критерій є визначальною характеристикою чогось (від грецьк. kritếrion - судити, kritēs - критик) - стандартний, еквівалентний - як мірило розрізнення, засіб судження - ознака, підстава, правило прийняття рішення щодо оцінки будь-чого на відповідність поставленим вимогам (Новиков, 2006). Слово «критерій» (criterion) грецького походження, яке перекладається як «засіб для рішення». В Енциклопедичному словнику «критерій» тлумачиться як ознака, на основі якої відбувається оцінка, визначення або класифікація чого-небудь; міра оцінки (Гора, 2018). Проблему визначення критеріїв і показників у педагогічному дослідженні опрацювали такі відомі педагоги, як: Ю. Бабанський, О. Барабанщиков, А. Корнілова наводить декілька визначень критеріїв: це показник, об'єктивний прояв чого-небудь; це психологічна установка діагностика; це мірило, тобто правило, яким треба користуватись при діагностуванні; це питання опитувальника, анкети, тести тощо (Корнілова, 2005). Визначений О. Семенюком зміст терміну «критерії» трактується як вимір оцінки, судження, а термін «рівні» - ступінь величини, розвитку, значущості чого-небудь (Семенюк, 2016). У контексті подальшого дослідження найбільш вичерпним вважаємо визначення поняття «критерій», сформульоване А. Галімовим: критерій виражає найзагальнішу сутність ознаку, на основі якої здійснюють оцінку, порівняння реальних педагогічних явищ, при цьому ступінь наяву, якісна спрямованість, визначеність критерію виражається у конкретних показниках (Галімов, 2004). Критерій допомагає прогнозувати, які результати й поведінку виявляє суб'єкт у певній ситуації. Критерії повинні бути наповнені відповідними показниками, які мають діагностичний характер.

Термін «показник», за «Новим тлумачним словником української мови», визначається як свідчення, доказ, ознака чого-небудь (Яременко, 2001). Як наголошує А. Семенова, показники фіксують певний рівень розвитку певного критерію. Показник - це явище або подія, за якими можна визначити динаміку певного процесу (Семенова, 2009). Показник як компонент або складова частина критерію $є$ типовим і конкретним виявом одної із суттєвих сторін досліджуваного явища, за яким можна судити не тільки про його наявність, а й про рівень його розвитку. При цьому кожен критерій буде розкрито через відповідні показники, за якими можна виявити рівень сформованості професійно-педагогічного підприємництва вчителя початкової школи.

У педагогічній науці визначено ознаки, яким повинні задовольняти критерії: критерії обов'язково мають бути об'єктивними (наскільки це дозволено в педагогіці), надавати можливість оцінювати ознаку чітко, не допускати оцінок, які можуть у подальшому призвести до сперечання; критерії потрібні, щоб бути адекватними, валідними, тобто оцінювати саме те, що дослідник хоче оцінити; критерії повинні бути нейтральними щодо аналізованих явищ і процесів.

Для педагогічного дослідження важливим $\epsilon$ визначення критерію того явища, на яке спрямоване дослідження. О. Максимова виділяє такі групи критеріїв: об'єктивні; результативні та процесуальні; нормативні та індивідуальноваріативні; наявного та прогностичного рівнів; професійного навчання і творчості; соціальної активності та професійної придатності; якісні та кількісні (Максимова, 2017). На думку А. Семенової, критерії класифікують таким чином: інтегральні критерій як оцінка загального стану явища або процесу; часткові критерії як оцінка складників явища або процесу; одиничні критерії як оцінка окремих сторін явища або процесу (Семенова, 2009).

Логічним також $\epsilon$ висновок, що критерій можна охарактеризувати не одним показником. Так, В. Тернопільська, О. Дерев'янко показник розглядають як типовий і конкретний прояв однієї із суттєвих сторін певної якості особистості; кількісні або якісні характеристики сформованості якості, властивості, ознаки об'єкта, що вивчають, ступінь сформованості того або іншого критерію (Тернопільська, Дерев'янко, 2012). Звідси випливає, що показники можуть мати кількісну і якісну оцінку. Практика проведення педагогічних досліджень свідчить, що критерії та показники є тим інструментарієм, за допомогою якого забезпечується можливість доведення сформульованих теоретичних припущень (гіпотез). 
Для оцінки сформованості професійно-педагогічного підприємництва вчителя початкової школи вважаємо доцільним використовувати різні сполучення параметрів і критеріїв та оцінювати рівні оволодіння поетапно, враховуючи кінцеві та проміжні цілі ії формування. Отже, в нашому дослідженні ми будемо виходити 3 того, що критерії та показники мають бути такими, щоб відбувалось оцінювання результатів поставленних завдань, які формують професійно-педагогічне підприємництво.

На нашу думку, при визначенні критеріїв та показників сформованості професійно-педагогічного підприємництва вчителів початкової школи необхідно врахувати інтегративний характер взаємозв'язку інваріантів їх професійної компетентності, що передбачає комп- лексний підхід до іï оцінювання. При цьому доцільно ураховувати: змістовні характеристики діяльності - комплекс внутрішніх спонукань, установок, мотивів до підприємницької діяльності, підприємницьку поведінку, рівень спрямованості інтересів тощо; процесуальні особливості професійного самовдосконалення. На основі аналізу науково-педагогічної літератури, застосування особистісно-діяльнісного підходу з дотриманням умов об'єктивності, адекватності, валідності, комплексності та інтегративності, а також враховуючи інформатизацію освітнього середовища, нами було визначено такі критерії та показники оцінювання сформованості професійно-педагогічного підприємництва вчителя початкової школи в умовах неперервної освіти (таблиця1).

Таблиця 1

Критерії та показники сформованості професійно-педагогічного підприсмництва вчителя початкової школи в умовах неперервної освіти (Джерело: розробка автора)

\begin{tabular}{|c|c|c|c|c|c|c|}
\hline Критерії & \multicolumn{6}{|c|}{ Показники } \\
\hline Мотиваційний & $\begin{array}{c}\text { ставлення } \\
\text { до підприємництва } \\
\text { прагнення до успіху }\end{array}$ & \multicolumn{2}{|c|}{$\begin{array}{c}\text { усвідомлення } \\
\text { соціальної } \\
\text { відповідальності } \\
\text { за результати } \\
\text { підприємницької } \\
\text { діяльності } \\
\end{array}$} & \multicolumn{2}{|c|}{$\begin{array}{c}\text { наявність внутрішньої } \\
\text { мотивації } \\
\text { до підприємницької } \\
\text { діяльності }\end{array}$} & $\begin{array}{c}\text { наявність зовнішньої } \\
\text { мотивації } \\
\text { до підприємницької } \\
\text { діяльності }\end{array}$ \\
\hline Когнітивний & \multicolumn{3}{|c|}{$\begin{array}{l}\text { наявність комплексних знань, необхідних } \\
\text { для здійснення підприємницької діяльності }\end{array}$} & \multicolumn{3}{|c|}{$\begin{array}{c}\text { сформованість методичних знань щодо } \\
\text { навчання підприємництву }\end{array}$} \\
\hline Діяльнісний & $\begin{array}{c}\text { сформованість } \\
\text { здатності до аналізу }\end{array}$ & \multicolumn{2}{|c|}{$\begin{array}{l}\text { сформованість } \\
\text { проектних умінь } \\
\text { і навичок }\end{array}$} & $\begin{array}{l}\text { сформованіст } \\
\text { організаторськ } \\
\text { та управлінськ } \\
\text { умінь і навичо }\end{array}$ & & $\begin{array}{c}\text { сформованість } \\
\text { навичок ефективної } \\
\text { комунікації }\end{array}$ \\
\hline $\begin{array}{l}\text { Особистісно- } \\
\text { рефлексивний }\end{array}$ & \multicolumn{2}{|c|}{$\begin{array}{l}\text { сформованість підпри- } \\
\text { ємницьких якостей } \\
\text { особистості }\end{array}$} & \multicolumn{2}{|c|}{$\begin{array}{l}\text { здатність до самоаналізу, } \\
\text { об’єктивної самооцінки }\end{array}$} & \multicolumn{2}{|r|}{$\begin{array}{l}\text { сформованість умінь } \\
\text { самокорекції }\end{array}$} \\
\hline Оцінний & \multicolumn{2}{|c|}{$\begin{array}{c}\text { вміння проявляти професійні } \\
\text { та фахові якості, вміння } \\
\text { самому приймати професійні } \\
\text { рішення; }\end{array}$} & \multicolumn{2}{|c|}{$\begin{array}{c}\text { вміння чітко проводити } \\
\text { самоаналіз і самооцінку } \\
\text { у професійній діяльності, } \\
\text { здатність до самооцінювання } \\
\text { своїх досягнень; }\end{array}$} & \multicolumn{2}{|c|}{$\begin{array}{c}\text { здатність постійно } \\
\text { самовдосконалюватись } \\
\text { та займатись самоосвітою; } \\
\text { потреба у професійній } \\
\text { діяльності до креативу; }\end{array}$} \\
\hline $\begin{array}{c}\text { Ціннісно- } \\
\text { орієнтаційний }\end{array}$ & \multicolumn{2}{|c|}{$\begin{array}{c}\text { сформованість професійного } \\
\text { інтересу; }\end{array}$} & \multicolumn{2}{|c|}{$\begin{array}{c}\text { потреба } \\
\text { у професійній самоосвіті } \\
\text { та самовдосконаленні }\end{array}$} & \multicolumn{2}{|c|}{$\begin{array}{l}\text { здатність долати перешкоди } \\
\text { у професійній діяльності. }\end{array}$} \\
\hline $\begin{array}{l}\text { Професійно- } \\
\text { пізнавальний }\end{array}$ & \multicolumn{2}{|c|}{$\begin{array}{c}\text { ступінь обізнаності } \\
\text { у використанні підприємни- } \\
\text { цьких методів та інформаційних } \\
\text { технологій для рішення } \\
\text { професійних задач; } \\
\end{array}$} & \multicolumn{2}{|c|}{$\begin{array}{c}\text { розвиненість } \\
\text { підприємницького мислення; }\end{array}$} & \multicolumn{2}{|c|}{$\begin{array}{c}\text { рівень сформованості } \\
\text { теоретичних професійних } \\
\text { знань } 3 \text { основ } \\
\text { підприємництва в освіті; }\end{array}$} \\
\hline $\begin{array}{l}\text { Функціонально- } \\
\text { компетентнісний }\end{array}$ & \multicolumn{2}{|c|}{$\begin{array}{c}\text { рівень сформованості } \\
\text { практичних умінь та навичок } \\
\text { вирішення професійних } \\
\text { завдань; }\end{array}$} & \multicolumn{2}{|c|}{$\begin{array}{l}\text { здатність керувати робочою } \\
\text { групою; }\end{array}$} & \multicolumn{2}{|c|}{$\begin{array}{c}\text { готовність до виконання } \\
\text { підприємницьких функцій } \\
\text { у реальних умовах; }\end{array}$} \\
\hline $\begin{array}{l}\text { Інформаційно- } \\
\text { інтегративний }\end{array}$ & \multicolumn{2}{|c|}{$\begin{array}{c}\text { здатність вільно орієнтуватися } \\
\text { в інформаційному } \\
\text { просторі при вирішенні } \\
\text { підприємницьких завдань;. }\end{array}$} & \multicolumn{2}{|c|}{$\begin{array}{c}\text { уміння спілкуватись засобами } \\
\text { ІКТ у професійній сфері }\end{array}$} & & $\begin{array}{l}\text { вміння інтегрувати } \\
\text { підприємництво } \\
\text { педагогічну практику }\end{array}$ \\
\hline
\end{tabular}


Мотиваційний критерій характеризується позитивним ставленням до підприємництва як суспільного явища, наявністю спрямованості до формування підприємництва, усвідомленням особистісної та професійної значущості знань, умінь та навичок у сфері підприємництва для використання в професійному розвитку та педагогічній діяльності, усвідомленою готовністю до вирішення професійних завдань, пов'язаних 3 необхідністю формування в учнів початкової школи підприємницьких якостей. Показниками такого критерію визначено як професійні, так і підприємницькі мотиви (потреба у досягненні, потреба у розвитку професіоналізму, потреби додатковго прибутку) та схильність до інновації. Потребу в досягненні визначаємо як прагнення досягти поставленої мети та мати успіх у діяльності - можна визначати через прагнення до вирішення професійних завдань та проблем, прояви ентузіазму під час отримання відсутньої професійно значущої інформації, готовність до відповідальності за їх наслідки, прагнення до взаєморозуміння та співпраці, потяг до нестандартного, оригінального вирішення професійного завдання.

Когнітивний - розкриває наявність базових соціально-економічних знань, що охоплюють знання про нормативно-правове регулювання, технологію організації та розвитку підприємницької діяльності, передумови та принципи успішного ведення бізнесу в освіті. Важливою складовою частиною когнітивного критерію $є$ ціннісні орієнтації, що грунтуються на педагогічних цінностях. Включення ціннісних орієнтацій до складу когнітивного критерію готовності учителів початкових класів до формування професійно-педагогічного підприємництва визначається тим, що готовність впливає на підприємницьку поведінку не прямо, а опосередковано - через цінності, норми, потреби вчителя та соціально-когнітивні процеси.

Діяльнісний - містить сформовані підприємницькі здатності щодо уміння вибору ефективної ідеї та способів іiі реалізації; здатність організовувати, планувати та прогнозувати результати підприємницької діяльності; уміння презентувати власні ідеї та проєкти; креативність; вміння налагоджувати конструктивні стосунки, керувати та контролювати хід і результати підприємницької діяльності.

Особистісно-рефлексивний - передбачає наявність підприємницьких якостей, здат- ність до самоаналізу, об'єктивної самооцінки, самокритики, готовність до подолання труднощів, виявлення та усунення їх причин, також включає якості, важливі для планування та ведення підприємницької діяльності (ініціативність, рішучість, самостійність, відповідальність, наполегливість, сміливість, схильність до розумного ризику, незалежність, комунікабельність, вміння працювати з людьми, встановлювати зв'язки, викликати довіру). Рефлексія при цьому визначається як джерело внутрішнього досвіду, спосіб самопізнання, необхідний інструмент управлінського мислення, здатність планувати власну діяльність, досягати виконання поставлених цілей та коректувати подальшу діяльність, аналізувати успіхи та складності у досягненні цілей.

Оцінний критерій містить такі показники, як самоконтроль, самоаналіз і самооцінка трудової діяльності, вміння адекватно оцінювати свої досягнення; прагнення до постійного фахового удосконалення, вияв вольових зусиль у вирішенні професійних проблем; творчість та креативність.

Ціннісно-орієнтаційний критерій характеризується розумінням ціннісних орієнтирів професійної діяльності, наявністю потреби бути конкурентоздатним фахівцем, вдосконалювати власну професійну компетентність через усвідомлення змісту трансформаційних процесів в початковій школі, сформованістю професійного інтересу, здатністю долати перешкоди у професійній діяльності.

Професійно-пізнавальний критерій визначає обсяг, глибину, мобільність теоретичних підприємницьких знань та здатність перенесення їх у професійно-практичну діяльність; ступінь обізнаності у використанні новітніх підприємницьких методів і технологій у професійній діяльності, розвиненість підприємницького мислення.

Функціонально-компетентнісний критерій характеризується ступенем сформованості практичних підприємницьких умінь та навичок щодо вирішення професійних завдань, у тому числі і засобами інформаційно-комунікаційних технологій, рівнем професійної самостійності при розв'язанні проблем і прийнятті управлінських рішень, здатністю керувати робочою групою при виконанні практичних завдань. 
Інформаційно-інтегративний критерій характеризується рівнем практичних умінь спілкування та вирішення інформаційних задач професійного та підприємницького характеру засобами IКТ. За інформаційно-інтерактивним критерієм вчитель зможе точно описати свої інформаційні потреби, швидко знайти, проаналізувати, обробити та використати знайдену інформацію, визначити шляхи подальших іiі пошуків для генерації нових знань в системі підприємництва в освіті.

Кожний із критеріїв є своєрідним взірцем, ідеалом, порівняння 3 яким дає можливість встановити ступінь відповідності отриманих результатів бажаним. Тому визначені нами критерії оцінювання конкретизуються показниками, що дають можливість точніше схарактеризувати рівні сформованості профе- сійно-педагогічного підприємництва вчителя початкової школи.

Висновки те перспективи подальших досліджень. Таким чином, визначені критерії i показники сформованості професійно-педагогічного підприємництва вчителя початкової школи забезпечать можливість проведення моніторингових досліджень із даної проблеми. Також у системі розроблених критеріїв та показників доцільно встановити мінімальне (порогове) значення, за якого можна констатувати їх сформованість і максимальне значення, а також говорити про високу імовірність використання сформованого професійно-педагогічного підприємництва вчителя в процесі його професійного розвитку та самореалізації. Перспективою подальших наукових розвідок $є$ добір та розробка відповідного діагностичного інструментарію.

\section{ЛІТЕРАТУРА:}

1. Гіжевський В.К., Головченко В.В., Ковальський В.С. Популярна юридична енциклопедія. Київ : Юрінком Інтер, $2002.528 \mathrm{c}$.

2. Галімов А.В. Теоретико-методичні засади підготовки майбутніх офіцерів-прикордонників до виховної роботи з особливим складом : монографія. Хмельницький, 2004. 376 с.

3. Гора Н.В. Педагогічні умови формування професійної компетентності майбутніх товарознавців. Молодий вчений. Педагогічні науки. 2018. № 6(58). С. 134-137.

4. Корнілова А. Ключові кваліфікації компетентності особистості у вищих навчальних закладах Німеччини. Шлях освіти. 2005. № 3. С. 18-22.

5. Максимова О.О. Методичні засади підготовки майбутніх вихователів ДНЗ до створення ситуації успіху в ігровій діяльності дітей. Митеиь - культура - виміри часу. Міжнародні наукові читання 2017 в Музеї Бориса Лятошинського в Житомирі: зб. Статей. Житомир : Вид. О.О. Євнок, 2017. С. 246-255.

6. Новиков А.М. Методология образования. Москва : «Эгвес», 2006. 488 с.

7. Семенова А.В. Парадигмальне моделювання у професійній підготовці майбутніх учителів : монографія. Одеса : Юридична література, 2009. 504 c.

8. Семенюк О. Ціннісна орієнтація як основа формування професійної компетентності. URL: http://apau.org. ua /2016/03/16/professyonalnaya-competence/ (дата звернення: 10.12.2021).

9. Тернопільська В., Дерев'янко О. Визначення критеріїв сформованості професійної компетентності майбутніх гірничих інженерів. Науковий часопис НПУ імені М.П. Драгоманова. Педагогічні науки: реалії та перспективи. 2012. № 31. С. 264-226.

10. Яременко В.В., Сліпушко О.М. Новий тлумачний словник української мови. Київ : Аконіт, 2001. Т. 2. 911 с.

\section{REFERENCES:}

1. Hizhevskyi V.K., Holovchenko V.V., Kovalskyi V.S. (2002) Populiarna yurydychna entsyklopediia. [Popular legal encyclopedia]. Kyiv : Yurinkom Inter. (in Ukrainian)

2. Halimov A.V. (2004) Teoretyko-metodychni zasady pidhotovky maibutnikh ofitseriv-prykordonnykiv do vykhovnoi roboty z osoblyvym skladom [Theoretical and methodological principles of training future border guards for educational work with a special staff:](monohrafiia), Khmelnytskyi. (in Ukrainian)

3. Hora N.V. (2018) Pedahohichni umovy formuvannia profesiinoi kompetentnosti maibutnikh tovaroznavtsiv. [Pedagogical conditions for the formation of professional competence of future commodity experts]. Molodyi vchenyi. Pedahohichni nauky, no. 6 (58). pp. 134-137. (in Ukrainian)

4. Kornilova A. (2005) Kliuchovi kvalifikatsii kompetentnosti osobystosti u vyshchykh navchalnykh zakladakh Nimechchyny. [Key qualifications of individual competence in German higher education institutions]. Shliakh osvity, no. 3. pp. 18-22. (in Ukrainian) 
5. Maksymova O.O. (2017) Metodychni zasady pidhotovky maibutnikh vykhovateliv DNZ do stvorennia sytuatsii uspikhu $\mathrm{v}$ ihrovii diialnosti ditei. [Methodical principles of preparation of future educators of secondary schools to create a situation of success in children's play activities]. Mytets - kultura - vymiry chasu. Mizhnarodni naukovi chytannia 2017 v Muzei Borysa Liatoshynskoho v Zhytomyri: zb. Statei. Zhytomyr : Vyd. O.O. Yevnok, pp. 246-255. (in Ukrainian)

6. Novykov A.M. (2006) Metodolohyia obrazovanyia. [Methodology of education]. Moskva : „Эhves”. (in Russia)

7. Semenova A.V. (2009) Paradyhmalne modeliuvannia u profesiinii pidhotovtsi maibutnikh uchyteliv [Paradigmatic modeling in the training of future teachers] (monohrafiia). Odesa : Yurydychna literatura. (in Ukrainian)

8. Semeniuk O. (2016) Tsinnisna oriientatsiia yak osnova formuvannia profesiinoi kompetentnosti. [Value orientation as a basis for the formation of professional competence]. URL: http://apau.org.ua/2016/03/16/professyonalnayacompetence/ (data zvernennia: 10.12.2021). (in Ukrainian)

9. Ternopilska V., Derevianko O. (2012) Vyznachennia kryteriiv sformovanosti profesiinoi kompetentnosti maibutnikh hirnychykh inzheneriv. [Determining the criteria for the formation of professional competence of future mining engineers] Naukovyi chasopys NPU imeni M.P. Drahomanova. Pedahohichni nauky: realii ta perspektyvy, no. 31. pp. 264-26. (in Ukrainian)

10. Iaremenko V.V., Slipushko O.M. (2001) Novyi tlumachnyi slovnyk ukrainskoi movy. [New explanatory dictionary of the Ukrainian language] Kyiv : Akonit. (in Ukrainian) 